\title{
Dairy Business Potential in Cuttack District of Odisha, India
}

\author{
Suvashree Ranjita Prusty*, Sarba Narayan Mishra and Sudhakar Tripathy \\ Department of Agricultural Economics, College of Agriculture, Orissa University of \\ Agriculture and Technology, Bhubaneswar, Odisha, 751003, India \\ *Corresponding author
}

\begin{abstract}
A B S T R A C T
\section{Keywords}

Dairy, Net return, Marketed surplus, Income equality, Business

\section{Article Info}

Accepted:

20 June 2018

Available Online:

10 July 2018

A study was carried out to estimate the cost and return, marketed surplus and income equality of milk in different type of dairy farms in Cuttack district of Odisha. The primary data were collected randomly from 120 numbers of dairy farmers. The percentage share of small, medium and large farmers was 34,54 and 12 respectively. Net return was higher in case of organized of ₹ 167.66 as compared to unorganized of ₹ 144.95 per day per cow. The average production, consumption and marketed surplus per day per household were ₹ 49.45, ₹ 4.96 and ₹ 44.491 in organised and ₹ 46.97, ₹ 5.21 and ₹ 41.761 in unorganized sector which indicated that both production and marketed surplus was higher in organized sector as compared to unorganized sector. All the farm sizes preferred to sell their produce to cooperative. In unorganized sector, all the farm sizes preferred to sell their produce to village trader followed by direct selling. Income of organized sector was more equally distributed than the unorganized one. Hence, it was suggested as dairy business was fine but till not reached the target, care should be taken for more and more yield by government incentive.
\end{abstract}

\section{Introduction}

Odisha contributes about 4.35 per cent population of livestock in the country in year 2013-14. About 85 per cent of livestock holding is held by landless and small or marginal farmers. It contributed 2 to 3 per cent of total milk production in India that is about 1.861 MT against 137 MT in 2013-14 from1.651 MT in 2009-10. Daily milk output is 60 lakh litres, but the amount processed is 5 to 6 lakh litres. It is observed that though the per capita availability of milk has increased from $67 \mathrm{~g} /$ day in 2000-01 to $117 \mathrm{~g} /$ day in
2013-14 (GOO, 2014). It is still far behind the all India per capita availability of milk 290 g/day in 2011-12 and world average of 285 $\mathrm{g}$ /day in 2011-12. Producer milk prices are 14 per cent higher in the informal sector than in formal sector (milk union cooperative). Various inputs like green fodder, dry fodder, concentrate, labour etc. are resources in milk production which are cheap and easily available. The price of milk differs from one channel to another through which milk surplus is marketed. Under such situation, it is worth to examine whether milk production is profitable or not. Cost and returns from 
dairying constitute an important aspect. Unemployed family labour, cheaply availed dry and green fodder, amenability with livestock, is a scope for Odisha dairy farmers mainly Cuttack district for livestock raising. Hence, a study was needed to find out milk marketing status in Cuttack district of Odisha.

The cooperative systems mitigates transaction costs, stimulates entry into market and promotes growth in technology mainly in rural area which expects more production, marketed surplus in each size of holding with more cross bred cows. The milk disposal pattern adopted by different size categories of milk producer is important aspect was focused in this paper with the attempt to examine the income distribution by two market structures of the milk producer.

\section{Materials and Methods}

Cuttack district was selected purposefully due to it's elevated milk production strategy. Two blocks such as Niali and Mahanga, were selected at random according to the milk market structure. Primary data on marketing of milk was collected by personal interview method with the help of pre-structured questionnaire.

A total of 120 farmers were selected by proportional rapid random sampling method from 2 villages i.e. Bagalpur and Pallisahi. About 9 large farmers (4 or more cows), 72 medium farmers (2-3 cows) and 36 small farmers (1 cow) and 82 farmers in organized and 38 farmers in unorganized sectors had been selected by proportional random sampling method in two phases with minimum deviation in the year 2015. The milk market structures taken were, organized sector, where state cooperative society i.e. OMFED was working and unorganized sector, where OMFED was not working with existence of informal milk market.

\section{Analytical tools used}

\section{Cost concepts and variables}

\section{Fixed cost}

It is the cost which is incurred whether the production is carried out or not. It includes depreciation and interest on fixed capital. Depreciation includes cow, cow-shed and equipment's cost keeping in view the present value and useful economic life of the capital asset.

\section{Variable costs}

Those are the costs which are incurred on the variable factors of production and can be altered in short run. It includes feed cost, labour cost, veterinary cost and miscellaneous cost.

\section{Gross cost}

It was obtained by adding all the cost components including fixed and variable costs, i.e.

Gross cost $=$ Total variable cost + Total fixed cost

\section{Net cost}

The net cost was computed by deducting the imputed value of dung, from gross cost, i.e.

Net cost $=$ Gross cost - Imputed value of dung

\section{Gross return}

It was obtained by multiplying milk yield of individual animal with respective prevailing prices in the study area, i.e.

Gross returns $=$ Quantity of milk $\times$ Market price of milk 


\section{Net returns}

Net return $=$ Gross returns - Net cost

Cost A: Value of green fodder + value of dry fodder + value of concentrate + depreciation on animals + depreciation on cow shed + depreciation on equipments + value of hired labour + veterinary and medical charges + miscellaneous expenditure (electricity and repairing expenses) + interest on working capital for dry period.

Cost B: Cost A + Imputed interest on fixed capital investment

Cost C1: Cost B + Imputed value of family labour

Cost C2: Cost $\mathrm{C}_{1}+10$ percent of the cost $\mathrm{A}$ (managerial cost of farmer)

\section{Break -Even output}

Break - Even Output $=$ Total fixed cost $(₹) /$ (Average selling price per 1 milk - Average variable cost per 1 milk)

\section{Marketable Surplus}

$\mathrm{MS}=\mathrm{P}-\mathrm{C}$

Where MS=Marketable Surplus

$\mathrm{P}=$ Gross production

$\mathrm{C}=$ Total requirement

\section{Marketed surplus}

It was used to denote the actual quantum of sales by the production irrespective of their requirements.

Marketed surplus may be less than, equal to or greater than marketable surplus.

\section{Gini concentration ratio}

It is used to know income distribution equality. It ranges between 0 and 1 . If $\mathrm{G}$ is equal to ' 0 ', that signifies that income is equally distributed, if $\mathrm{G}$ is equal to ' 1 ', it signifies income is totally unequally distributed. If $\mathrm{G}$ ranges between 0 and 1 , income is unequally distributed.

$\mathrm{G}=1-\left\{\sum \mathrm{x}_{\mathrm{i}}\left(\mathrm{y}_{\mathrm{i}}+\mathrm{y}_{\mathrm{i}-1}\right)\right\} / 10,000$

Where, $x_{i}=$ Percentage of household

$y_{i}=$ Cumulative percentage of income of household

$\mathrm{n}=$ Number of household

\section{Results and Discussion}

\section{Distribution of dairy farms}

The sampled dairy producers were classified into three categories viz. Small, medium and large farmers according to amount of milk produced per day per household. The classified pattern of milk producers was presented in the Table 1. From the table it is found that all total of milk producers were producing milk of the range of 15-75 1 per day. Highest number of farmers viz. 41 numbers producing about 15 to 451 of milk per day. The percentage share of small, medium and large farmers categories are 34, 54 and 12 respectively. Kaur et al., (2010) found that 28,38 and 34 percentage share of farmers were small, medium and large.

Cost and returns for milk production according to market structure

The daily maintenance cost per day per cow with all it's cost and return of cross bred cow is shown in Table 2. The total cost was worked out as ₹ 163.23 per day per animal which varied between ₹ 156.72 for unorganized and ₹ 169.73 for organized sector. The fixed cost is worked out to be ₹ 18.520 , ₹ 13.844; variable cost is ₹ 151.21 , $₹ 142.88$ in organized and unorganized sector with overall fixed and variable costs are ₹ 
16.18 , ₹ 147.04 respectively. The overall share of total variable cost, fixed cost to total cost was 94.06 and 5.96 percent out of which $10.91,89.08$ percent overall share of organize sector and 13.84, 91.16 of unorganized sector. Feed cost accounts highest to overall variable costs, i.e. $40.92,30.47$ percent in case of organized and unorganized, out of which concentrate contributes highest to total feed cost. Veterinary cost is next highest cost followed by labour cost to total variable costs. Whereas gross return is highest in case of organize i.e. ₹ 337.40 as compare to unorganized $₹ 301.367$. It is found that net return, higher in case of organized of ₹ 167.66 as compared to unorganized of ₹ 144.95 per day per cow. Similar finding i.e. net return for the member of organized sector is higher than the unorganized sector in Rajasthan (Tanwarl, Yogendra and Sankhala, 2012). Cost $A$, cost $B$, cost $C_{1}$, cost $C_{2}$ are higher in case of organized as compared to unorganized one.

\section{Break even analysis}

The market structure wise break-even level of output was worked out shown in Table 3. It is shown that the total milk produced per milch cow per day in organized and unorganized sector is 11.641 and 10.731 respectively which are much higher than the break-even level of output i.e. $1.28 \quad 1$ and $1.03 \quad 1$ respectively. Thus, it can be concluded that the brake-even output was achieved earlier in unorganized sector than organized sector. Small herd size group of dairy farms achieved the break-even level first than other herd size group reported by (Singh and Rai, 1998).

Average production, consumption and marketed surplus of milk by members of organized and unorganized groups

The average production, consumption and marketed surplus of organized and unorganized market structure with various farm sizes have been shown in Table 4. The average production, consumption and marketed surplus per day per household are $49.45,4.96$ and 44.491 for organized sector whereas in unorganized sector it was 46.97 , 5.21 and 41.761 which indicated that both production and marked surplus is higher in organized sector as compared to unorganized sector. The marketed surplus of small, medium and large farmers of organized sector are 13.58, 39.22 and 65.351 respectively whereas in unorganized sector it is somewhat lower i.e. 8.72, 36.67 and 62.93 respectively. Farmers of member group have higher marketed surplus in comparison to non member of cooperative (Kaur et al, 2010).

\section{Pattern of milk disposal}

A perusal of Table 5 indicated that the marketed surplus of milk was disposed off by the producers according to preference and importance they gave to each outlet. In organized sector, on an average 35.661 of milk is disposed to cooperative, 3.181 is sold directly to consumer. In unorganized sector, on an average 50.821 of milk is disposed to village trader and 12.091 is directly sold to consumer.

Table.1 Distribution of commercial dairy farms according to milk production per day per household

\begin{tabular}{|l|c|c|c|}
\hline Producer category & Milk production & No. of dairy farms & percentage \\
\hline Small & Up to 151 & 41 & 34 \\
Medium & 15 to 451 & 65 & 54 \\
Large & 45 to 751 & 14 & 12 \\
Total & & 120 & 100 \\
\hline
\end{tabular}


Table.2 Cost and return of milk production per day per cow according to the market structure

\begin{tabular}{|c|c|c|c|}
\hline Cost Items & Organized & Unorganized & Overall \\
\hline \multicolumn{4}{|l|}{ 1.FIXED COST } \\
\hline TOTAL FIXED COST & $\begin{array}{c}18.52 \\
(10.91)\end{array}$ & $\begin{array}{l}13.84 \\
(8.83)\end{array}$ & $\begin{array}{c}16.18 \\
(9.91)\end{array}$ \\
\hline \multicolumn{4}{|l|}{ 2.VARIABLE COST } \\
\hline \multicolumn{4}{|l|}{ a)Feed cost } \\
\hline i)Green fodder & $\begin{array}{l}10.52 \\
(6.19)\end{array}$ & $\begin{array}{c}8.89 \\
(5.67)\end{array}$ & $\begin{array}{c}9.70 \\
(5.94)\end{array}$ \\
\hline ii)Dry fodder & $\begin{array}{l}8.756 \\
(5.15)\end{array}$ & $\begin{array}{l}9.157 \\
(5.84)\end{array}$ & $\begin{array}{l}8.956 \\
(5.48)\end{array}$ \\
\hline iii)Concentrate & $\begin{array}{c}69.46 \\
(40.92)\end{array}$ & $\begin{array}{c}58.73 \\
(37.47)\end{array}$ & $\begin{array}{c}64.09 \\
(39.26)\end{array}$ \\
\hline Total feed cost & $\begin{array}{c}88.74 \\
(52.28)\end{array}$ & $\begin{array}{c}92.98 \\
(59.33)\end{array}$ & $\begin{array}{r}90.86 \\
(55.64)\end{array}$ \\
\hline b)Family labour & $\begin{array}{c}17.46 \\
(10.28)\end{array}$ & $\begin{array}{c}16.19 \\
(10.33)\end{array}$ & $\begin{array}{c}16.83 \\
(10.31)\end{array}$ \\
\hline c)Hired labour & $\begin{array}{c}4.34 \\
(2.56)\end{array}$ & $\begin{array}{c}2.99 \\
(1.90)\end{array}$ & $\begin{array}{c}3.67 \\
(2.24)\end{array}$ \\
\hline Total labour cost & $\begin{array}{c}17.81 \\
(12.84)\end{array}$ & $\begin{array}{c}19.08 \\
(12.23)\end{array}$ & $\begin{array}{c}20.50 \\
(12.55)\end{array}$ \\
\hline d)Veterinary expense & $\begin{array}{c}32.52 \\
(19.162)\end{array}$ & $\begin{array}{c}21.73 \\
(13.86)\end{array}$ & $\begin{array}{c}27.13 \\
(16.62)\end{array}$ \\
\hline e)Miscellaneous expense & $\begin{array}{c}8.13 \\
(4.79)\end{array}$ & $\begin{array}{c}8.97 \\
(5.72)\end{array}$ & $\begin{array}{c}17.10 \\
(10.48)\end{array}$ \\
\hline TOTAL VARIABLE COST & $\begin{array}{l}151.215 \\
(89.08)\end{array}$ & $\begin{array}{l}142.88 \\
(91.16)\end{array}$ & $\begin{array}{l}147.04 \\
(90.08)\end{array}$ \\
\hline TOTAL COST & 169.73 & 156.72 & 163.23 \\
\hline 3.Interest on working capital & 41.86 & 44.30 & 43.08 \\
\hline 4. Value of dung & 18.59 & 15.55 & 17.07 \\
\hline 5.Milk production & 11.64 & 10.73 & 11.18 \\
\hline 6.Saling price of milk & 27.38 & 26.65 & 27.01 \\
\hline GROSS RETURN & 337.40 & 301.68 & 319.36 \\
\hline NET RETURN & 167.66 & 144.95 & 160.87 \\
\hline 7. Cost A & 190.84 & 182.05 & 186.45 \\
\hline 8. Cost B & 194.13 & 184.83 & 189.44 \\
\hline 9. Cost $C_{1}$ & 211.60 & 201.03 & 206.31 \\
\hline 10. Cost $C_{2}$ & 232.76 & 221.13 & 226.94 \\
\hline
\end{tabular}


Table.3 Break even output of milch cow in different market structure (Per day in litre)

\begin{tabular}{|l|c|c|c|c|c|c|c|c|}
\hline $\begin{array}{c}\text { Market } \\
\text { structure }\end{array}$ & $\begin{array}{c}\text { Milk } \\
\text { yield per } \\
\text { cow } \\
\text { (l) }\end{array}$ & $\begin{array}{c}\text { Fixed } \\
\text { cost per } \\
\text { cow } \\
\text { (₹) }\end{array}$ & $\begin{array}{c}\text { Variable } \\
\text { cost per } \\
\text { cow } \\
(\mathbf{(})\end{array}$ & $\begin{array}{c}\text { Total cost } \\
\text { per cow } \\
(\mathbf{F})\end{array}$ & $\begin{array}{c}\text { Variable } \\
\text { cost per I } \\
\text { of milk } \\
\text { (₹) }\end{array}$ & $\begin{array}{c}\text { Price } \\
\text { per I of } \\
\text { milk } \\
\text { (₹) }\end{array}$ & $\begin{array}{c}\text { Break } \\
\text {-even } \\
\text { output } \\
\text { (l) }\end{array}$ & $\begin{array}{c}\text { Percentage of } \\
\text { brake even } \\
\text { output to total } \\
\text { output }\end{array}$ \\
\hline Organized & 11.64 & 18.52 & 151.21 & 169.73 & 12.98 & 27.38 & 1.28 & 11.0 \\
\hline Unorganized & 10.73 & 13.84 & 142.88 & 156.72 & 13.30 & 26.65 & 1.03 & 9.65 \\
\hline Overall & 11.18 & 16.18 & 147.04 & 163.23 & 13.14 & 27.01 & 1.16 & 10.42 \\
\hline
\end{tabular}

Table.4 Average production, consumption and marketed surplus of milk in organized and unorganized sector, per day per household (in litre)

\begin{tabular}{|l|c|c|c|c|c|c|}
\hline category & Organized & & Unorganized & \\
& Production & Consumption & $\begin{array}{l}\text { Marketed } \\
\text { surplus }\end{array}$ & Production & Consumption & $\begin{array}{l}\text { Marketed } \\
\text { surplus }\end{array}$ \\
\hline Small & 15.64 & 2.06 & 13.58 & 10.75 & 2.03 & 8.72 \\
& $(100.00)$ & $(13.82)$ & $(86.18)$ & $(100.00)$ & $(18.89)$ & $(81.11)$ \\
\hline Medium & 43.96 & 4.74 & 39.22 & 41.56 & 4.89 & 36.67 \\
& $(100.00)$ & $(10.79)$ & $(89.21)$ & $(100.00)$ & $(11.76)$ & $(88.24)$ \\
\hline Large & 71.73 & 6.38 & 65.35 & 69.87 & 6.94 & 62.93 \\
& $(100.00)$ & $(8.90)$ & $(91.10)$ & $(100.00)$ & $(9.93)$ & $(90.07)$ \\
\hline overall & 49.45 & 4.96 & 44.49 & 46.97 & 5.21 & 41.76 \\
& $(100.00)$ & $(10.03)$ & $(89.97)$ & $(100.00)$ & $(11.11)$ & $(88.90)$ \\
\hline
\end{tabular}

Table.5 Milk disposal pattern of different categories of milk producers (litre per day per household)

\begin{tabular}{|l|c|c|c|c|}
\hline \multirow{2}{*}{ Category } & \multicolumn{2}{|c|}{ Organized } & \multicolumn{2}{c|}{ Unorganized } \\
\cline { 2 - 5 } & Cooperative & Direct selling & Direct selling & Village trader \\
\hline Small & 13.66 & 1.98 & 2.24 & 8.51 \\
& $(87.34)$ & $(12.65)$ & $(20.84)$ & $(79.16)$ \\
\hline Medium & 35.98 & 3.24 & 7.11 & 29.56 \\
& $(91.73)$ & $(8.27)$ & $(19.39)$ & $(80.61)$ \\
\hline Large & 60.42 & 4.94 & 12.36 & 50.57 \\
& $(92.78)$ & $(7.55)$ & $(19.65)$ & $(80.35)$ \\
\hline overall & 35.66 & 3.18 & 12.09 & 50.82 \\
& $(91.82)$ & $(8.18)$ & $(19.22)$ & $(80.77)$ \\
\hline
\end{tabular}


Table.6 Distribution of households' income for organized and unorganized market structure

\begin{tabular}{|c|c|c|c|c|c|c|c|c|}
\hline \multirow[b]{2}{*}{$\begin{array}{c}\text { Income group (rupees } \\
\text { / household) }\end{array}$} & \multicolumn{4}{|c|}{ Organized Members } & \multicolumn{4}{|c|}{ Unorganized Member } \\
\hline & $\begin{array}{l}\text { Number of } \\
\text { household }\end{array}$ & $\begin{array}{l}\text { Percentage of } \\
\text { household }\end{array}$ & $\begin{array}{l}\text { Average } \\
\text { income per } \\
\text { household }\end{array}$ & $\begin{array}{l}\text { Percentage } \\
\text { of income }\end{array}$ & $\begin{array}{l}\text { Number of } \\
\text { household }\end{array}$ & $\begin{array}{c}\text { Percentage } \\
\text { of } \\
\text { household }\end{array}$ & $\begin{array}{c}\text { Average } \\
\text { income per } \\
\text { household }\end{array}$ & $\begin{array}{l}\text { Percentage } \\
\text { of income }\end{array}$ \\
\hline Less than 10,000 & 1 & 1 & 5126.12 & 2.10 & 3 & 9.23 & 4032.00 & 2.00 \\
\hline $10,000-15,000$ & 14 & 17.56 & 7590.02 & 3.45 & 11 & 29.45 & 8043.84 & 3.99 \\
\hline $15,000-20,000$ & 17 & 21.01 & 17292.53 & 7.86 & 10 & 28.12 & 12096.23 & 6.00 \\
\hline $20,000-25,000$ & 11 & 14.01 & 18512.96 & 8.41 & 8 & 21.35 & 18103.89 & 8.98 \\
\hline $25,000-30,000$ & 18 & 20.32 & 22990.23 & 10.45 & 2 & 6.45 & 21086.56 & 10.41 \\
\hline $30,000-35,000$ & 7 & 7.99 & 27632.56 & 12.56 & 1 & 1.56 & 28454.16 & 14.01 \\
\hline $35,000-40,000$ & 7 & 8.01 & 37158.35 & 16.89 & 1 & 1.02 & 31510.08 & 15.63 \\
\hline $40,000-45,000$ & 4 & 5.42 & 40524.34 & 18.42 & 1 & 1.24 & 37195.29 & 18.45 \\
\hline $45,000-50,000$ & 3 & 4.12 & 43693.11 & 19.86 & 1 & 1.49 & 42993.28 & 20.53 \\
\hline overall & 82 & 100 & 220000.12 & 100 & 38 & 100 & 201600.23 & 100 \\
\hline $\begin{array}{l}\text { Gini concentration } \\
\text { ratio }\end{array}$ & \multicolumn{4}{|c|}{.6957} & \multicolumn{4}{|c|}{.8437} \\
\hline
\end{tabular}

Figure.1 Lorenz curve for member of organized and unorganized market structure

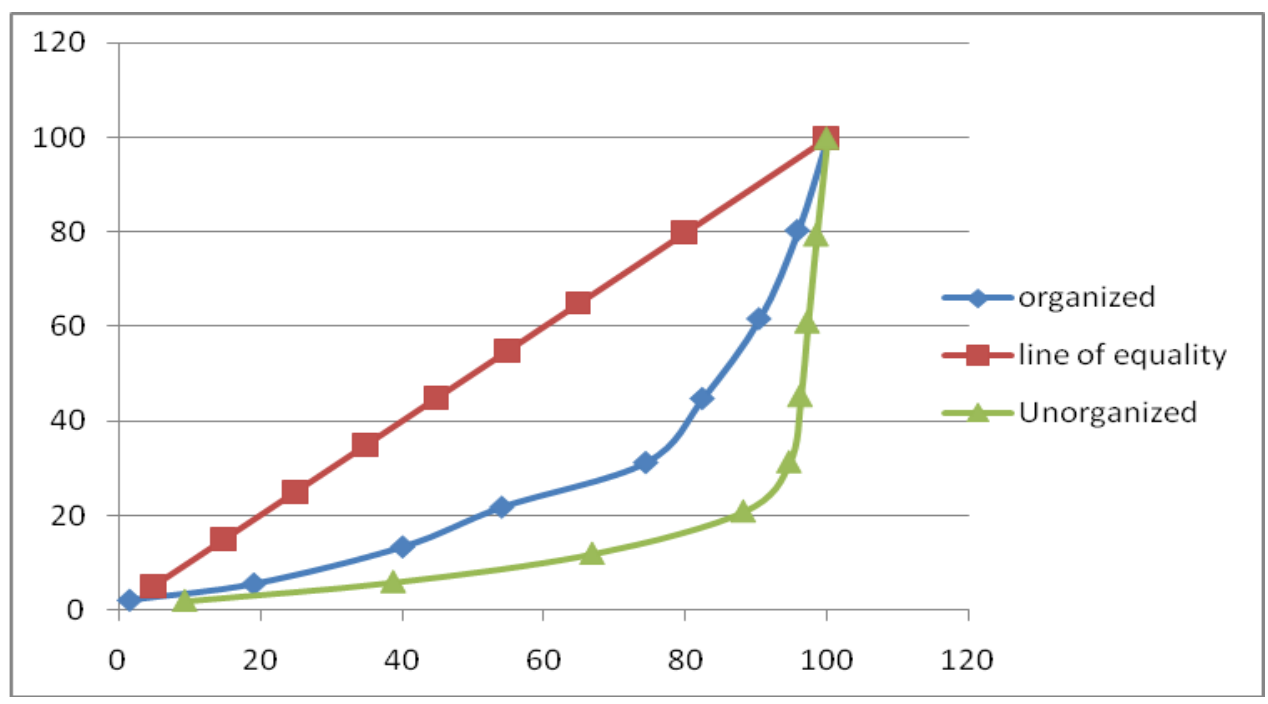

All the farm sizes preferred to sell their produce to cooperative i.e. 91.82 percentage next preference was direct selling i.e. 8.18 percentage in organized sector. In unorganized sector, all the farm sizes preferred to sell their produce to village trader i.e.80.77 percentage followed by direct selling i.e.19.22 percentage respectively. Yogi et al, 2007 found that largest amount of milk is disposed to unorganized sector in which milk vendor procured highest amount of milk in Rajasthan. Similar findings are reported by
Sangu (1997), Singh and Rai (1998) and Vedamurthy hand Chauhan (2005).

\section{Pattern of income distribution}

Pattern of gross income distribution from dairy was shown in Table 6 . The result shown that, the average gross income of organized group is significantly higher than the unorganized. A better method provided by Lorenz curve (which taken into account the income of all units as well as their 
distribution) shown that 1.56 percent of members shared only 2.10 percent of income while 20.32 percent of household shared 10.54 percent of income in case of member of organized sector. In case of unorganized sector, 9.23 percent of household shared 2.00 percent of income, 29.45 percent of household which is highest among all household shared 3.99 percent of income. Gini concentration ratio for organized sector is .6957 while it is .8437 for unorganized sector, which shown that the income of organized sector is more equally distributed than the unorganized one because $G$ value lied more towards 0 , that is clearly shown by Lorenz curve in Figure 1.

In conclusion, dairy farming scored high through additional income and generated gainful employment, as a result of dairy cooperatives. It can go along way in boosting up more income and employment level. It is evident from the result of study that highest number of farmers i.e. 54 percentage produce milk at a range of 15-45 1 followed by small and large. Least numbers about 12 percentage of farmers yield highest range up to 75.1 of milk per day. Organized sector had highest milk marketed surplus as compared to unorganized one. All the farm sizes preferred to sell their produce to cooperative i.e. 91.82 percentage next preference is direct selling i.e. 8.18 percentage in organized sector. In unorganized sector, all the farm sizes preferred to sell their produce to village trader i.e. 80.77 percentage followed by direct selling i.e. 19.22 percentage respectively. Income of organized sector is more equally distributed than the unorganized. The study area has achieved good result on dairy business as it have high milk marketed surplus. Cooperative sector also played a major role in milk marketing by procuring highest amount of milk and more income equality. Hence, it is suggested that, as dairy business is profitable due to high production but till not reached the target. Care should be taken for more yield by government incentive and implication of good technology. Emphasis should be on organized sector for better milk marketing.

\section{References}

Brithal, P.S. (2008). Linking small holder livestock producers to markets, Indian Journal of Agricultural Economics, 63(1), 19-37.

Government of Odisha, (2014). Statistical Survey Database.

Kaur, P., Kaur, K., and Singh, P. (2010). Milk Market Structure in Punjab - Organized vs. Unorganized sector. Indian Journal of Agricultural Marketing, 24 (2), 8491.

Sangu, K.P.S. (1997). Price spread of milk under different channels of marketing. Indian Dairy Man. 49(1), 29-32.

Singh,V. and Rai, K.N. (1998). Economics of production and marketing of buffalo milk in Haryana. Indian Journal of Agricultural Economics. 53(1), 41-52.

Tanwar, P. S. Kumar, Y and Sankhala, G. 2012. Economics of milk production among member and non-member families of dairy cooperatives in Jaipur (Rajasthan). Indian Journal of Dairy Science, 65(5), 405-409.

Vedamurthy, K.B. and Chauhan, A.K. (2005). Economic analysis of milk marketing in Shimoga District of Karnataka, Indian Journal of Agricultural Marketing. 19(2), 39-51.

Yogi, R.K., Chauhan, A.K., and Sharma, S.P. (2007). Economics of milk marketing in Jaipur district of Rajasthan, Indian Journal of Dairy Science, 60(4), 307312.

\section{How to cite this article:}

Suvashree Ranjita Prusty, Sarba Narayan Mishra and Sudhakar Tripathy. 2018. Dairy Business Potential in Cuttack District of Odisha. Int.J.Curr.Microbiol.App.Sci. 7(07): 2735-2742. doi: https://doi.org/10.20546/ijcmas.2018.707.320 